\title{
Critical Manufacturing Prerequisites for Successful Reshoring
}

\author{
David Eriksson \\ Department of Supply Chain and Operation Management, School of Engineering, \\ Jönköping University, P.O. Box 1026, SE-551 11, Jönköping, Sweden \\ Email: dr.d.eriksson@gmail.com (Corresponding Author) \\ Per Hilletofth \\ Department of Industrial Engineering and Management, \\ University of Gävle, SE-801 76, Gävle, Sweden \\ Department of Supply Chain and Operations Management, School of Engineering, \\ Jönköping University, P.O. Box 1026, SE-551 11, Jönköping, Sweden \\ Email: prof.p.hilletofth@gmail.com
}

Wendy L. Tate

Department of Marketing and Supply Chain Management, University of Tennessee, Knoxville, TN, USA

Email: wendy.tate@utk.edu

\author{
Mikael Göthager \\ Department of Management Consulting, \\ CANEA Partner Group, Packhusgatan 6, SE-411 13, Göteborg, Sweden \\ Email: mikael.gothager@canea.se
}

\begin{abstract}
Reshoring is an emergent theme in research and practice. It is important for researchers to understand the motivating force and prerequisites for these reshoring activities, and to develop a method that supports sustainable reshoring decisions. The purpose of this study is to shed light on the prerequisites for successful reshoring. The preparation for this study consists of a systematic literature review. The findings presented here, however, are revelatory and emerged during a workshop. The findings were further researched at a total of four companies, which were part of data collection in a larger project. This research identified three scenarios, in which preceding manufacturing step, creation of parallel steps, or exploration of overcapacity are central. The paper also presents a stage-gateprocess for reshoring decisions as well as a typology of reshoring alternatives. This research sheds light on prerequisites and contextual factors that enable companies to reshore. The importance of manufacturing capabilities can be seen in literature, but has not yet, to our knowledge, been given sufficient attention. The main practical implication is related to offshoring. Overly-aggressive offshoring can complicate future reshoring. As such, reshoring needs to be considered during offshoring, specifically what manufacturing capabilities that are kept at the domestic location.
\end{abstract}

Keywords: sourcing, offshoring, backshoring, outsourcing, insourcing, reshoring manufacturing location decision

\section{INTRODUCTION}

To give a historic overview of how humans have acquired resources it is possible to go back to the dawn of men. Nomads moved to where resources were available, and settlers located and shaped their environment to accommodate their needs. As a result of specialization and uneven distribution of resources, trade has been an integral part of human life since these times. In the modern era, through the reduction of trade barriers, improved transportation infrastructure and IT-support (Hilletofth, 2008), humans have been able to establish fast and efficient trade on a global level. In an effort to gain competitive advantage, companies have moved supply bases to low-cost regions (Taplin, 2006). In many cases, however, this move has had negative impacts (e.g. Kinkel and Maloca, 2009), due to unanticipated business results, supporting that global sourcing decisions are highly complex.

In response to problems associated with global sourcing from low-cost countries, there is an emergence of research, which has significant implications for manufacturing in high-cost environments, particularly with respect to reshoring. Arik (2013, p. 75) defines reshoring as "the reversal of the previously offshored business activities". And even though variants exist, a similar definition is adopted by other researchers (Bailey and De Propris, 2014; Ellram et al., 2013; Gylling et al., 2015; Martínez-Mora and Merino, 
2014; Tate et al., 2014). Reshoring is a specific variation of the manufacturing location decision, which has received much more research attention (McIvor, 2013). Sometimes companies have chosen to locate manufacturing at an offshore location, but due to issues such as currency volatility (Fine, 2013), theft of intellectual property (Pearce, 2014), and ill-motivated decisions (Kinkel and Maloca, 2009), they are now considering the reshoring of manufacturing. Despite the emergence of the field, and its economic importance, little is known about the contextual factors that are important for a reshoring decision (Foerstl et al., 2016).

The distinction of context is not always easy, but it is an important part in many approaches within social sciences (Danermark et al., 2003). The context has ability to not only affect the magnitude of an event, the context can also be necessary for the event to occur - or cancel the event entirely (Sayer, 1992). If the event considered is reshoring, these contextual factors affecting the reshoring decision are often talked about in terms of enablers and barriers (e.g. Wiesmann et al., 2017). These factors include issues pertaining to global economy (Kazmer, 2104), distances in the supply chain (Martínez-Mora and Merino, 2014), and the market (Wu and Zhang, 2014). Despite a large amount of research in this area, there is a lack of research focusing on existing manufacturing in the home country, which is strange as the reshored manufacturing is likely to have a dependency with the already present manufacturing.

The overarching purpose of this paper is to shed light on the prerequisites for successful reshoring. The focus is not on financial metrics, as this has previously been assessed, notably by using transaction cost economy (TCE) and resource based view (RBV) (Ellram, 2013; McIvor, 2013). Instead, this research centers on the role of in-house manufacturing and processes still performed by the focal company as it affects reshoring of other manufacturing steps. Two research questions have been formulated to focus specifically on existing manufacturing and its role as a facilitator for reshoring.

1. What is the role of existing manufacturing, in the home country of the focal company, for reshoring?

2. How should existing manufacturing capabilities be incorporated in a reshoring decision?

The research questions are complementary and follow a progression from the first to the second. Answering the questions will contribute to increased knowledge about the prerequisites for reshoring. The remainder of the paper is structured as follows: the next section presents a typology of offshoring and reshoring terminology, as well as an overview of reshoring research. This is followed by the methodology of the paper which describes the case companies, and process for collecting data. The remaining portion discusses the results, conclusions, implications and future research.

\section{LITERATURE REVIEW}

Reshoring, as described by other researchers, can be understood in the more conventional supply terminology of choice among supply markets and supply channels. These are typically discussed in terms of make or buy and domestic or international location decision (Fraering and Prasad, 1999) (Figure 1).

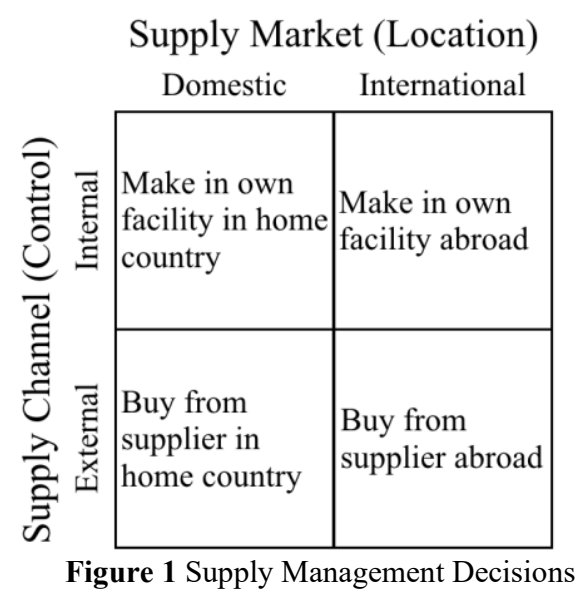

In those definitions, it can be assumed that reshoring is preceded by an earlier movement of manufacturing to an offshore location. While several authors have this view (e.g. Arik, 2013; Kazmer, 2104), Tate et al. (2014) use a definition of reshoring that does not necessitate previously offshored manufacturing. This is important, as potential problems with reshoring might manifest, whether or not the activities were previously offshored. For example, a company might gain control of activities at an offshore location due to corporate takeover. Due to the novelty of the field, it is not yet fully understood if these types of activities encounter the same type of problems as activities that were previously offshored, if they are reshored. As there is not much known about this field, and it is difficult to find rich data, both types of reshoring scenarios are considered, when discussing prerequisites in manufacturing related to domestic production.

To avoid confusion in terminology and in practice, it is important to first separate offshoring from outsourcing. Grossman and Rossi-Hansberg (2006, p. 3), also highlight the potential source for confusion and use 'offshore' to refer to "the performance of tasks in a country different from where a firm's headquarters are located", and 'outsourcing' is referred to as "the performance of tasks under some contractual arrangement by an unrelated party". Note that while the terms are different they are not mutually exclusive; the potential combinations are visualized in Figure 2.

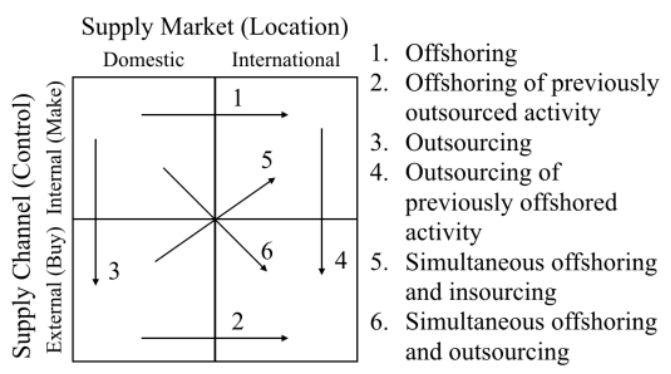

Figure 2 Overview of Offshoring and Outsourcing Terminology

Turning to reshoring, there is the same confusion in terminology (Fratocchi et al., 2014). Drawing on Grossman and Rossi-Hansberg (2006), a similar logic is applied to the 
potential alternatives, but 'in reverse'. The potential combinations are visualized in Figure 3.

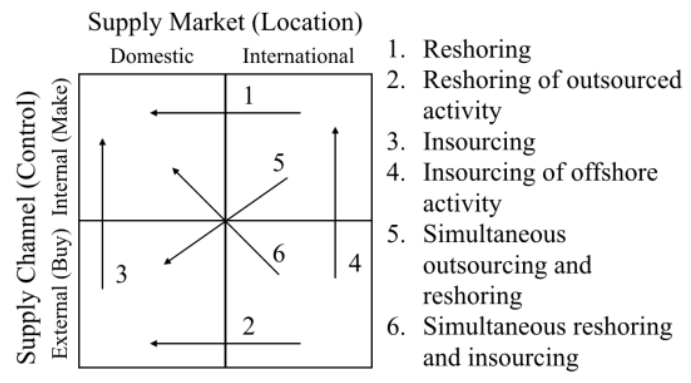

Figure 3 Overview of Reshoring and Insourcing Terminology

With the basic terminology established, it is important to highlight that make or buy and location decisions concern a steady state (if products should be bought or manufactured in-house, where manufacturing should be located), whereas the offshoring and reshoring terminology necessitates a movement of an activity (if production should be moved to a domestic location or to an international location).

The plethora of different versions of reshoring from Figure 3 is also evident by the diversity of concepts available in the literature (Wiesmann et al., 2017; Barbieri et al., 2018). Four main categories of reshoring terminology were identified. These are 'reshoring' (Arik, 2013; Bailey and De Propris, 2014; Ellram, 2013; Gylling et al., 2015; MartínezMora and Merino, 2014; Tate et al., 2014), 'backshoring' (Arlbjørn and Mikkelsen, 2014; Canham and Hamilton, 2013; Kinkel and Maloca, 2009), 'onshoring' (Kazmer, 2104), and 'back-reshoring' (Fratocchi et al., 2014). All these terms are different and have their own nuances, both within and between terms, but they all share the notion that manufacturing is moving (back) to the 'home country' of the company, which is the definition used in this paper.

One of the earlier papers on reshoring highlights that companies considering offshoring often do so on cost-based models that do not account for the diverse factors that influence both the decision and its outcomes (Kinkel and Maloca, 2009). Arik (2013) expands on previously simplistic models, creating a model for offshoring and reshoring decision. He includes firm-specific factors, the domestic competitive environment, and global competitive dynamics. Fratocchi et al. (2014) include reshoring in a broader decision process, which is a general strategic approach to internationalization of manufacturing. Following the decision to move manufacturing abroad, they include factors such as governance structure (internal vs. external control), and if the outsourced manufacturing should be made to a geographically proximal or distant position. Gray et al. (2017) include firm's cost and performance factors into a decision-making model based on heuristics and considers mental rules for assessing gap between actual and expected cost/performance factors. Hilletofth et al. (2019) include six criteria from firm's competitive priorities to develop a fuzzy logic model based on heuristics to support decision-making.

While the decision might not yet be sufficiently developed, reasons for reshoring have been identified in literature. These can be divided into five main groups: (1) 'global competitive dynamics', (2) 'host country', (3) 'supply chain', (4) 'home country', and (5) 'firm-specific' (Wiesmann et al., 2017). These groups factors have been observed in case study findings (Engström et al., 2018a; 2018b). These are found in Table 1.

Table 1 Reasons for Reshoring (adapted from Wiesmann et al., 2017)

\begin{tabular}{|c|c|}
\hline Group & Factor \\
\hline \multirow{5}{*}{ Global competitive dynamics } & Political risks \\
\hline & Changes in global economy \\
\hline & Eroding comparative advantages \\
\hline & Instability in exchange rates \\
\hline & Increased competition on resource assets \\
\hline \multirow{6}{*}{ Host country } & Diminishing growth opportunities \\
\hline & Inadequate quality \\
\hline & Theft of intellectual property and weak patent enforcement \\
\hline & High employee turnover \\
\hline & Lack of trust and commitment among staff or suppliers \\
\hline & Risk of public relation disaster due to supplier malfeasance \\
\hline \multirow{8}{*}{ Home country } & Political incentives \\
\hline & Promote community (domestic goodwill) \\
\hline & Access to qualified personnel \\
\hline & Increased degree of automation \\
\hline & Higher productivity and work morale among staff \\
\hline & Increased awareness of environmental impact \\
\hline & Increased focus on sustainability \\
\hline & Strengthen brand through "made in" \\
\hline \multirow{6}{*}{ Supply chain } & Innovation, research and development suffers due to the distance to manufacturing \\
\hline & High coordination costs \\
\hline & Risk of disruption \\
\hline & Importance of and issues with delivery performance (speed and dependability) \\
\hline & Difficulties to match production (supply) and consumption (demand) volumes \\
\hline & Growing demand for and shortages of accessible transportation \\
\hline
\end{tabular}




\begin{tabular}{|l|l|}
\hline \multirow{4}{*}{ Firm specific } & Inability to provide services related to the product \\
\cline { 2 - 2 } & Increased demand on customization \\
\cline { 2 - 2 } & Difficulties due to physical and mental distance \\
\hline & Wrong estimation of benefits and risks in the offshoring decision \\
\cline { 2 - 2 } & Lack of knowledge about the host country during the offshoring decision \\
\cline { 2 - 3 } & Overhasty offshoring decisions (bandwagon effect) \\
\cline { 2 - 2 } & Over-estimation of cost savings during the offshoring decision \\
\hline
\end{tabular}

In the groups presented in Table 1, the separation of factors has been based on geography, but there is also a separation of factors based on organizational structure. 'Supply chain' is the first group related to organizational structure. The group includes factors related to the flows of goods and information. These include high coordination and transaction costs (Arlbjørn and Mikkelsen, 2014), increasing demand for customization (Pearce, 2014), and physical and mental distance (Kinkel, 2014). The organizational version of the global-local interplay presented above, is complemented with a group of 'firm-specific' factors. These include incorrect risk-benefit analysis during offshoring (Kinkel and Maloca, 2009), immature offshoring decision (Gray et al., 2013), and over estimation of cost savings (Canham and Hamilton, 2013). Currently, the field of reshoring is growing and reshoring in relation to manufacturing prerequisites, other than Industry 4.0 (Ancarani et al., 2019; Dachs et al., 2019), is a topic which is not yet discussed. To address this, empirical examples of the importance of existing manufacturing facilities is discussed.

\section{METHODOLOGY}

Prior to data collection, the research was prepared by conducting a structured literature review on reshoring. The literature review included both quantitative and qualitative analysis. The quantitative analysis was descriptive, and the qualitative analysis followed the model of categorizing and pattern-matching outlined by Mayring (2010). The qualitative analysis of the literature organized the findings into different factors related to reshoring. These were used to deduce what types of empirical findings that could be expected in the empirical research. Due to the specifics of the case study herein presented, the findings from the quantitative analysis are left out.

The empirical data used in this paper is gathered from a case study (Eisenhardt, 1989) including four multinational companies, active in Sweden. One company has acted as the primary case company (MainCo), as the data from that company contained the richest information of the topic discussed here. The case company was initially selected as it seeks to move production to the home country, but there are differing opinions within the company of how the cost of the move should be calculated. Studying the company, it became clear that the role of their already existing production was central to their reshoring. This revelation can be seen a crossroad, where the research took a new direction (Eriksson and Engström, 2020). To investigate deeper, primary focus was given to the main company, but to better understand the findings we decided to see if the same phenomena could be seen at other companies. Three other companies (SubCoA, SubCoB, SubCoC) have been used as complementary case companies in efforts to triangulate the findings (Yin, 2009), and to direct and redirect the research (Dubois and Gadde, 2002). As MainCo included all examples of reshoring scenarios discussed, the empirical example presented in this paper revolves around this company. A brief overview about the companies is presented in Table 2.

Table 2 Case-company overview

\begin{tabular}{lccr} 
Company & Industry & $\begin{array}{c}\text { Number of } \\
\text { employees }\end{array}$ & Revenue \\
MainCo & $\begin{array}{c}\text { Material handling } \\
\text { equipment }\end{array}$ & 1,100 & $\begin{array}{c}€ 280 \\
\text { million }\end{array}$ \\
\hline SubCoA & $\begin{array}{c}\text { Manufacturer heavy } \\
\text { equipment }\end{array}$ & 100 & $\begin{array}{c}€ 30 \\
\text { million }\end{array}$ \\
& $\begin{array}{c}\text { Observation } \\
\text { SubCoB }\end{array}$ & 120 & $\begin{array}{c}€ 50 \\
\text { million }\end{array}$ \\
& Garment & 10 & $€ 2$ milliion \\
SubCoC & manufacturer/brand & &
\end{tabular}

The data collection consisted of workshops, observations and interviews. Initially, workshops were conducted with MainCo, SubCoA, and SubCoB. Due to the sensitive nature of the matters discussed at MainCo and SubCoA, it was not possible to make voice recordings during some data collection when suppliers were discussed. The workshops resulted in an interest of prerequisites for reshoring, and a preliminary model was constructed. To compensate for the lack of recorded data, initial findings and models were instead verified and updated in a joint effort with key informants from MainCo. Semi-structured interviews were then conducted, to better understand reshoring, including a specific focus on prerequisites.

The interviews contributed to a further understanding of prerequisites to reshoring related to manufacturing. The voice-recorded interviews were transcribed, and emerging themes were captured in open coding (Ellram, 1996). The categories that formed from this analysis helped to further the understanding of prerequisites to reshoring related to manufacturing. The data collection was concluded with the inclusion of SubCoC. It is a company that has been part of earlier research, and it was expected that the company could be used as an illustrative case (Yin, 2009) and to construct a better narrative (Dyer and Wilkins, 1991). Prior to the interview, the respondent was given a draft of the paper and asked to consider if and how SubCoC could contribute to the 
empirical examples. The respondent was also allowed to suggest changes to the text, as well as read all drafts. A detailed summary of the data collection is available in Table 3 .

Table 3 Summary of Data Collection

\begin{tabular}{|c|c|c|c|c|c|}
\hline No. & Company & $\begin{array}{l}\text { Type of data } \\
\text { collection }\end{array}$ & Duration & $\begin{array}{l}\text { Data collection } \\
\text { method }\end{array}$ & Job title of respondents \\
\hline 1 & MainCo & Workshop & $2 \mathrm{~h}$ & $\begin{array}{l}\text { Note taking }+ \\
\text { Voice recording }\end{array}$ & $\begin{array}{l}\text { Controller Products, Manufacturing Engineering Manager, } \\
\text { Purchasing Manager, Vice President Manufacturing. }\end{array}$ \\
\hline 2 & MainCo & Workshop & $3 \mathrm{~h}$ & Note taking & $\begin{array}{l}\text { Controller Products, Industrial Engineer, Manufacturing Engineering } \\
\text { Manager, Strategic Buyer (two), Purchasing Manager, Supplier } \\
\text { Quality, Vice President Manufacturing. }\end{array}$ \\
\hline 3 & MainCo & Observation & $1 \mathrm{~h}$ & Note taking & Controller Products, Purchasing Manager, Supplier Quality. \\
\hline 4 & MainCo & Interview & $1 \mathrm{~h}$ & $\begin{array}{l}\text { Voice recording } \\
+ \text { Note taking }\end{array}$ & Manager quality Engineering, Supplier Quality. \\
\hline 5 & MainCo & Interview & $1 \mathrm{~h}$ & $\begin{array}{l}\text { Voice recording } \\
+ \text { Note taking }\end{array}$ & Controller Products. \\
\hline 6 & MainCo & Interview & $1 \mathrm{~h}$ & $\begin{array}{l}\text { Voice recording } \\
+ \text { Note taking }\end{array}$ & Purchasing Manager, Strategic Buyer. \\
\hline 7 & MainCo & Interview & $1 \mathrm{~h}$ & $\begin{array}{l}\text { Voice recording } \\
+ \text { + Note taking }\end{array}$ & Vice President Manufacturing. \\
\hline 8 & MainCo & Interview & $1 \mathrm{~h}$ & $\begin{array}{l}\text { Voice recording } \\
+ \text { Note taking }\end{array}$ & Industrial Engineer, Manufacturing Engineering Manager. \\
\hline 9 & SubCoA & Workshop & $2 \mathrm{~h}$ & Note taking & Financial Manager, Marketing Director, Product Engineering. \\
\hline 10 & SubCoA & Observation & $1 \mathrm{~h}$ & Note taking & Financial Manager, Product Engineering. \\
\hline 11 & SubCoB & Workshop & $3 \mathrm{~h}$ & $\begin{array}{l}\text { Voice recording } \\
+ \text { Note taking }\end{array}$ & $\begin{array}{l}\text { Human Resources Manager, Manager Supply Chain Management, } \\
\text { Managing Director, Quality Manager, Vice President Production. }\end{array}$ \\
\hline 12 & SubCoB & Observation & $1 \mathrm{~h}$ & Note taking & Respondents: Vice President Production. \\
\hline 13 & SubCoB & Interview & $1.5 \mathrm{~h}$ & $\begin{array}{l}\text { Voice recording } \\
+ \text { Note taking }\end{array}$ & Manager Supply Chain Management, Vice President Production. \\
\hline 14 & SubCoB & Interview & $1.5 \mathrm{~h}$ & $\begin{array}{l}\text { Voice recording } \\
+ \text { note taking }\end{array}$ & $\begin{array}{l}\text { Production Development Manager, Quality Manager, Vice President } \\
\text { Production }\end{array}$ \\
\hline 15 & SubCoB & Interview & $2 \mathrm{~h}$ & Note taking & Managing Director, Vice President Production. \\
\hline 16 & SubCoC & Interview & $1 \mathrm{~h}$ & Note taking & Member of owning family. \\
\hline
\end{tabular}

The preparations for the workshops, observations and interviews were of a deductive nature. The instrument for the interviews was a semi-structured interview guide, covering issues related to why companies reshored, based on the above-mentioned literature review. The preparations made it possible to extract much information during the interviews. The findings most central for this specific paper emerged from the empirical setting and is of an inductive nature (Kovács and Spens, 2005). During this data collection, the researchers were invited as participants discussing previous and historical reshoring projects. As such, there was no specific instrument employed, but the familiarity with the current research stated, gained through the literature review, was important. Emergent findings from the first workshop were drafted into a preliminary model (Figure 7). Workshops were then held with SubCoA and SubCoB, who each discussed one reshoring case, of which they had great familiarity. This was followed by a second workshop with MainCo, with the goal of discussing reshoring projects. Findings from the first workshop were discussed and the preliminary model was presented. The final data collection central to this paper, was a workshop at SubCoC, conducted in the same manner as with the other SubCoS.

Earlier and future projects were discussed based on the preliminary model from MainCo. Once the empirical work was complete, an article draft was presented to respondents at MainCo, which gave input on the text. Following this stage, SubCoC was included to finalize the research. This work followed guidelines on how to improve the trustworthiness of the research (Lincoln and Guba, 1985). Several researchers argue that the critical realist ontology (Bhaskar, 1978) is suitable for case research in this field (Aastrup and Halldórsson, 2008; Easton, 2010), and trustworthiness has been argued a suitable quality criteria with this research approach (Eriksson, 2015). The efforts are summarized in Table 4. Case studies have, in logistics and supply chain research, have often been shoehorned into positivistic research (Aastrup and Halldórsson, 2008). Research is not always strong in all trustworthiness criteria, and sometimes all are not applicable.

Different scenarios for reshoring emerged inductively during a workshop with MainCo (number two in Table 3). As we were not allowed to record this session, note taking was used. The different scenarios were based on what types of activities the company sought to reshore. Due to the datacollection method, it is not possible to provide a chain of evidence from data to results (Yin, 2009), and instead we had to rely on prolonged engagement, persistent observation, member checks and triangulation (Lincoln and Guba, 1985). While the lack of raw data is a weakness, we do believe that the other employed quality techniques are sufficient to accept the claims here presented. The specific scenarios, and where the data was gathered, is outlined in Table 5. 
Table 4 Trustworthiness in the Case (Based on Lincoln and Guba, 1985)

\begin{tabular}{ccc}
\hline Trustworthiness Criterion & Description & Application \\
\hline Credibility & & \\
\hline
\end{tabular}

Prolonged engagement

Being involved in the empirical setting long enough to understand the context in which the phenomenon is being studied.
Three separate data collections at MainCo, complemented with four activities as SupCoA and SupCoB, and work with MainCo presenting the findings.

\begin{tabular}{|c|c|c|}
\hline Persistent observation & $\begin{array}{l}\text { Take the time needed to reach sufficient depth in the } \\
\text { research. }\end{array}$ & $\begin{array}{l}\text { Model was discovered and validated by MainCo. Afterwards it was } \\
\text { verified with SupCoA and SupCoB and MainCo. }\end{array}$ \\
\hline Member checks & $\begin{array}{l}\text { Crosschecking data to ensure a true picture. Flick (2009) } \\
\text { include four types of triangulation: data, investigator, } \\
\text { theory, and methodological. }\end{array}$ & $\begin{array}{l}\text { The same phenomenon was investigated multiple times, at three } \\
\text { companies, and by a total of four researchers and two undergraduate } \\
\text { students. }\end{array}$ \\
\hline Triangulation & Allow informants to review the data. & $\begin{array}{l}\text { Respondents at MainCo has reviewed early models and the } \\
\text { presentation of the findings. }\end{array}$ \\
\hline Transferability & $\begin{array}{l}\text { To provide a thick description that allows someone } \\
\text { interested to determine if a transfer of the findings is } \\
\text { possible. }\end{array}$ & $\begin{array}{l}\text { The methodology and case description are detailed. However, } \\
\text { generalization is not the goal of critical-realism research. The work } \\
\text { has instead been focused on a deeper understanding of the } \\
\text { mechanisms that are important for reshoring decisions. }\end{array}$ \\
\hline Confirmability & $\begin{array}{l}\text { The assessment of the product of the research and the } \\
\text { consistency between theory, framework, data, and } \\
\text { findings. }\end{array}$ & $\begin{array}{l}\text { This is a careful expansion of reshoring theory in a novel area. } \\
\text { Several tactics, such as triangulation and persistent observation has } \\
\text { increased consistency between data and findings. The data and } \\
\text { findings are related to reshoring literature, but as the field has not } \\
\text { previously investigated this area it is hard to create consistency with } \\
\text { established theory. } \\
\text { 'Open coding' was used in the data analysis. }\end{array}$ \\
\hline
\end{tabular}

Table 5 Open Coding of critical manufacturing capabilities (Based on Ellram, 1996)

\begin{tabular}{|c|c|c|c|c|}
\hline \multirow[b]{2}{*}{$\begin{array}{l}\text { Activity } \\
\text { no. }\end{array}$} & & \multicolumn{2}{|c|}{ Different reshoring scenarios discovered during empirical studies } & \multirow[b]{2}{*}{$\begin{array}{l}\text { Reshoring of steps that exploit } \\
\text { overcapacity }\end{array}$} \\
\hline & & $\begin{array}{l}\text { Reshoring of directly preceding } \\
\text { manufacturing steps }\end{array}$ & $\begin{array}{l}\text { Reshoring of parallel manufacturing } \\
\text { steps }\end{array}$ & \\
\hline 1 & $\begin{array}{l}\text { MainCo, } \\
\quad \text { first } \\
\text { workshop }\end{array}$ & $\begin{array}{l}\text { Examples of module manufacturing that } \\
\text { had previously been reshored and were } \\
\text { currently considered for reshoring. } \\
\text { Discovered in first workshop. }\end{array}$ & $\begin{array}{c}\text { A specific reshoring project of a product } \\
\text { line was presented during the first } \\
\text { workshop. }\end{array}$ & $\begin{array}{l}\text { During the first workshop considerations } \\
\text { to reshore to better utilize equipment were } \\
\text { presented. }\end{array}$ \\
\hline 2 & SubCoA & $\begin{array}{l}\text { Financial Manager and Product } \\
\text { Engineering presented a previously } \\
\text { offshored and later reshored product. The } \\
\text { part is produced independently, and } \\
\text { assembled to the final product. }\end{array}$ & No examples. & No examples. \\
\hline 3 & SubCoB & $\begin{array}{l}\text { A potential reshoring project that is } \\
\text { currently under consideration was } \\
\text { presented. It is a module that is } \\
\text { independently produced in different } \\
\text { configurations and assembled with other } \\
\text { parts at a later stage in manufacturing. }\end{array}$ & No examples & No examples \\
\hline 4 & $\begin{array}{l}\text { MainCo, } \\
\text { second } \\
\text { workshop }\end{array}$ & $\begin{array}{l}\text { Based on the findings from the first } \\
\text { workshop and the findings from SubCoA } \\
\text { and SubCoB, the scenario was presented } \\
\text { and discussed. }\end{array}$ & $\begin{array}{l}\text { Based on the findings from the first } \\
\text { workshop, the scenario was presented and } \\
\text { discussed. }\end{array}$ & $\begin{array}{l}\text { Based on the findings from the first } \\
\text { workshop, the scenario was presented } \\
\text { and discussed. }\end{array}$ \\
\hline 5 & SubCoC & No examples. & $\begin{array}{l}\text { Offshoring followed by reshoring of parallel } \\
\text { manufacturing steps was discussed to add } \\
\text { content to the scenario. }\end{array}$ & $\begin{array}{l}\text { Reshoring based on overcapacity in } \\
\text { manpower was introduced as an } \\
\text { alternative to overcapacity in equipment. }\end{array}$ \\
\hline
\end{tabular}

In all cases, the importance of existing manufacturing emerged as a critical factor for reshoring decisions. The quest of the research has been to continually work toward a better understanding about reshoring, which is context-dependent and an ongoing process (Dubois and Gadde, 2002; Eriksson, 2015).

\section{EMPIRICAL EXAMPLE}

MainCo was originally a family-owned business located in Sweden. But through business growth and changes in corporate structure, the company is now part of an international conglomerate of companies. Their past, and current reshoring and insourcing decisions are discussed and presented in three distinct examples, which were identified when collecting and analyzing data. The first example considers the recapture of a manufacturing step, which is directly preceding the first manufacturing step currently performed in the facility. The second example considers the recapturing of manufacturing steps that are similar to steps already present in the facility, creating parallel production of one or more steps. The third example considers recapture of steps that exploit overcapacity, such as low use of a critical equipment or increased use of floor space. These categories were first suggested by the researchers and later presented to the company. Before discussing these in detail, the context in which the decisions were taken is presented. 
Starting in 2004, MainCo began working with lean production (Ohno, 1988). Over the course of more than ten years, they continued manufacturing the same volume of products, but have reduced their operating time from two shifts to one shift. In addition to the implementation of lean principles, this improvement in efficiency is also the result of increased automation. The plant originally used a fixed position layout, that is when manpower and equipment are moved to the product which is manufactured at one stationary location. The manufacturing schedule was based on calendar weeks, and most of the products were finished on Fridays, but with no real way of knowing exactly how long it would take to complete one specific product.

As a part of the many improvements made to the manufacturing process, development toward a line-based production process was initiated in 2005, increasing efficiency and delivery precision. Additionally, the company worked with increased modularization, which enables both manufacturing benefits (economy of scale) and improved service due to fewer spare parts. The company has always had the competency needed to perform certain manufacturing processes, but it has mostly been centered on welding and assembly. Internal data about production volumes shows that the number of units produced is about the same in 2016 as it was in 2005. However, in 2005 the factory was operating two shifts per day, and is now only operating one shift each day.

Parallel to the improvements in production, reshoring decisions have been taken mainly on a case basis focused on cost. MainCo describes the decisions as typical make-or-buy evaluations. For example, a certain part is used in almost all product lines, but it varies in length. It must therefore be ordered for each specific model, as it is hard for the company to predict demand on individual lengths. Moreover, the length of the part makes for costly transportation as the product is shipped on a pallet, with no real possibility of utilizing the volume of the pallet in a good way. Other financial considerations include the determination and inclusion of overhead costs.

So far, reshoring activities at MainCo have had a strong connection to the present manufacturing capabilities. The different connections could be coded into three specific scenarios (see Ellram, 1996, p. 110, 'open coding'): reshoring of directly preceding manufacturing steps, reshoring of parallel manufacturing steps, and reshoring of steps that exploit overcapacity in equipment. The first scenario was also identified in SubCoA and $\mathrm{SubCoB}$, and the second and third scenarios were also identified at SubCoC. The scenarios are discussed in detail below.

\subsection{Reshoring of Directly Preceding Manufacturing Steps}

Both supply chains and manufacturing processes contain 'steps' of activities that shape the final product. MainCo controls the very last steps in this long, global chain. The controller of product explains this decision accordingly: "The founder had this philosophy. The company should be an assembly station where components are bought. The first truck was assembled in his kitchen." This fragmentation of manufacturing steps across different actors came to pose a problem for MainCo; a few products had many variants and were costly to transport, and due to the corporate structure. Also, they needed to order parts in a wide variety of colors depending on how the product was branded and customer preference. This caused multiple problems. First, the delivery lead times of products were long because the different variants were ordered after the customer order was placed. Secondly, painted parts could get scratched during transport and might need touch up. Finally, modules that are assembled and painted by a supplier require more transportation volume compared to the flat parts that constitute the model.

SubCoA experienced this type of reshoring following the offshoring and outsourcing of a part that is attached to the primary product. Even though it is a specific part, the part is produced in a similar manner and with the same machines as several other parts produced by SubCoA, so they maintained the manufacturing knowledge internally. When quality problems arose from the supplier, the SubCoA was ready to once again produce the part in their own facility.

If directly preceding manufacturing steps are reshored, several benefits might be gained. These include, but are not limited to: better fill rates in transportation, as components can be shipped in flat boxes prior to being assembled; and shorter lead-times, as it is possible to keep parts (instead of modules) in inventory.

As might be noted, reshoring of directly preceding manufacturing steps necessitates that some steps are still controlled in-house. These already controlled steps almost act as 'seeds', to which other manufacturing steps can be attached (Figure 4). For each step that is reshored it is necessary to ensure the right competency and equipment are still available. This is not a dramatic change, but an expansion of current competencies. MainCo has already performed this type of reshoring, with positive results.

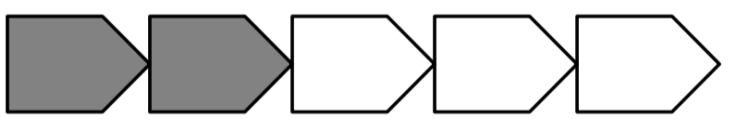

Figure 4 Reshoring of Directly Preceding Manufacturing Steps (Grey Steps Reshored)

Based on this empirical example, the following is proposed:

Proposition 1a: Focusing on the manufacturing steps that are performed before those present in the manufacturing facility increases the success in reshoring.

\subsection{Reshoring of Parallel Manufacturing Steps}

The second scenario discussed is highly dependent on manufacturing with a line-based layout and modularization. In a corporate takeover, MainCo gained control of a manufacturing facility at an offshore location. The other facility manufactured one specific variant of the same type as MainCo. Due to the complex corporate structure, the other facility already shared modules with the products manufactured at the company. MainCo already had multiple manufacturing lines, producing different products, but with shared or similar modules. As such, it was assumed that the production relocation would be manageable, as in-house competence about similar manufacturing. It was therefore decided to reshore this specific variant and manufacture it in a parallel line (Figure 5). 


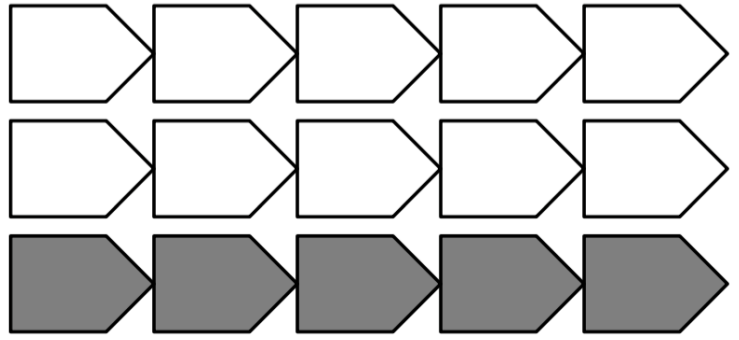

Figure 5 Reshoring of Parallel Manufacturing Steps (Grey Steps Reshored)

For SubCoC the scenario was similar. In the early 2000's they moved production and machines to an offshore location, while keeping capacity for small batches and product development in the home country. SubCoC struggled to keep a consistent quality at the offshore location, due to a heterogeneous raw material, requiring machine operators to have a good 'feel' for the product. About ten years after offshoring, it was apparent that the strategy did not work and the company initiated reshoring. The reshored production lines work in parallel with the existing product development and small-batch production line. Whereas the quality is highly dependent on the knowledge of the operator, there is an uneven workload with much effort being spent on setup, after which the machines can be left alone. Accordingly, when reshoring was considered, it was estimated that the operators would have time to run more machines at the same time and they already had knowledge about how to operate the machines.

For this type of reshoring it is important to have space in the facility, and to be able to increase both the number of employees and manufacturing equipment. However, in all of the steps that are reshored, MainCo and SubCoC already had in-house competency for both people, process, and equipment. It is therefore possible to distribute the available competency across new and old lines, and simultaneously educate new employees in the manufacturing system.

Based on this empirical example, the following is proposed:

Proposition 2: The creation of parallel manufacturing capabilities increases the success of reshoring and improves existing resource utilization.

\subsection{Reshoring of Steps that Exploit Overcapacity}

The third reshoring scenario is a bit different from the other two, as this is a decision that is still being discussed by MainCo. The company has invested in an expensive machine that performs jobs on all product categories. However, the machine is not fully utilized, and to have a positive economic result with the new machine, it is necessary to increase its utilization. For MainCo, this is also true with most other operation in the plant. The company is currently running on shift, and it is therefore possible to double the workload without any real investments in infrastructure or added overhead costs.

To better utilize the expensive machine, managers have been looking to reshore components that utilize the activity performed by this machine. The steps followed by the machine are already performed in-house. This decision has not been as straight forward, as there are several financial metrics that need to be assessed. Most are similar to a typical make or buy decision, but they also revolve around how to calculate the costs for the machine, and how it should affect the price of the product. The main discussion revolves around whether or not already existing over-head costs should be added to the cost for the reshored products, or if only direct costs should be included (Figure 6).

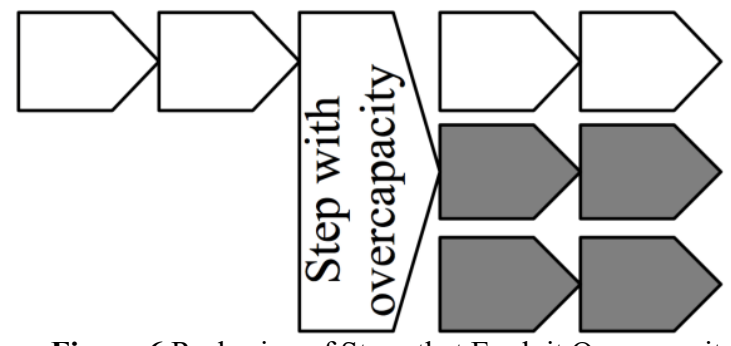

Figure 6 Reshoring of Steps that Exploit Overcapacity (Grey Steps Reshored)

At first, this scenario considered overcapacity in equipment, but SubCoC showed how the same scenario can be applicable to overcapacity in manpower. As discussed in the previous scenario, SubCoC's products are dependent on the operator having a 'feel' for the quality. When starting a new production batch there is a long downtime, due to internal set-up activities. It is also important to inspect the first product, as to ensure that the quality is correct. Following the set-up and inspection, the machine requires only minimal control, and the operator is free to perform other activities. As was the case with MainCo, SubCoC had a lot of unused capacity, but in the form of manpower. As a consequence, the decision to reshore production and machines did not drive the cost of manpower, but can be seen as an opportunity through economy of scale.

Based on this empirical example, the following is proposed:

Proposition 3a: Reshoring manufacturing steps that exploit existing manufacturing capacity increase the success of the reshoring effort and improves resource utilization.

Proposition 3b: Considering only marginal costs in the reshoring decisions increases the success of the reshoring effort and improves resource utilization.

\section{DISCUSSION}

The empirical findings show three contextual issues, directly related to existing manufacturing in the home country, that are important for reshoring. Based on these scenarios, a model of antecedents to and outcomes from reshoring is proposed (Figure 7). Existing manufacturing, parallel manufacturing capabilities, and exploitation of overcapacity in concert with appropriate cost models increase the success in reshoring and improves resource utilization as noted in the developed propositions. 
Antecedents

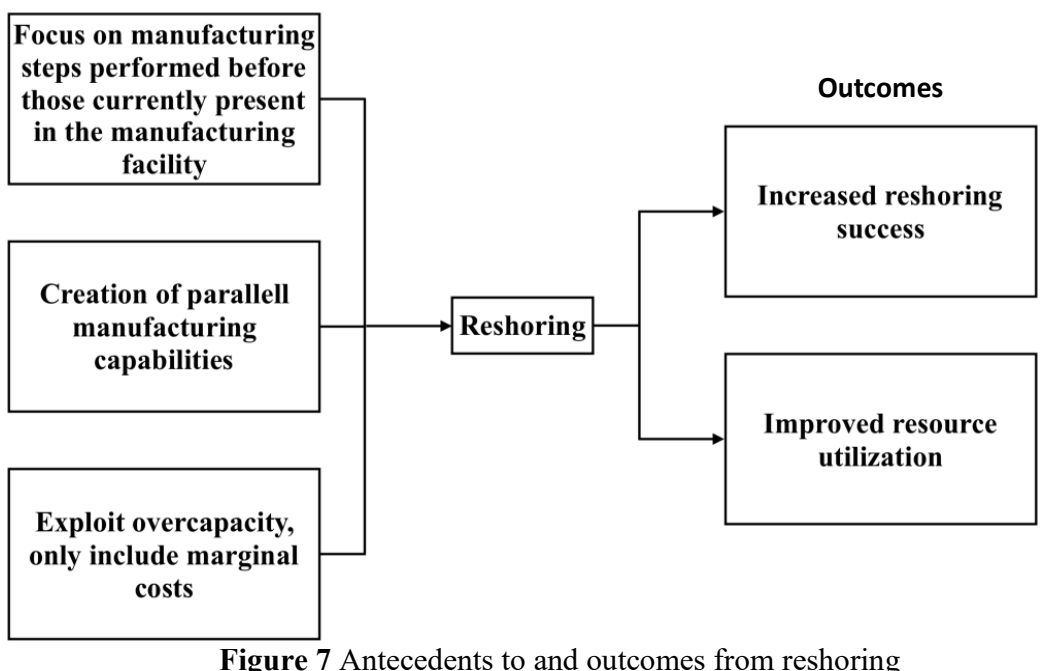

Figure 7 is only based on reshoring in relation to existing manufacturing and is thus only one part of contextual factors that need to be considered. However, based on these three specific scenarios, a model of beneficial reshoring scenarios can begin to be developed. The model can be seen as a 'stage-gate system', where positive input from each category is needed to deem the overall scenario as beneficial (Figure 8). The first category is 'manufacturing prerequisites'. This category is certainly not yet fully explored, but three scenarios have been identified that seem important for successful reshoring. In the model, as was discussed with MainCo, it was chosen to include a saving condition for each category. This is to acknowledge that sometimes it might be necessary to continue to evaluate a reshoring decision, even if not all conditions are ideal. The second category is a generic representation of how future categories can be added to the model. The final category $(n)$ is 'financial feasibility'. This category is considered important due to the need of companies to generate profits, and is supported by the fact that there has been a high focus on financial metrics (e.g. Ellram, 2013) and managerial issues (e.g. Martínez-Mora and Merino, 2014) in earlier reshoring research.

The study was designed to increase knowledge about specific events (Eriksson, 2015) and not to create generalizable findings according to a positivistic paradigm. The model also adds to existing knowledge in such a way that the findings are trustworthy. It might seem obvious that it is easier to expand existing manufacturing compared to starting new factories and manufacturing processes. However, as several companies fail in their attempts to offshore (Wiesmann et al., 2017), it might be important to include this insight already when offshoring. Besides the generic assumption made above, this study provides three specific examples of the role of existing manufacturing for reshoring. A key question in future research is to find thresholds of how much, or what type of, manufacturing that needs to be present in-house, to facilitate successful reshoring.

The primary theoretical implication of this research is that it is necessary to not only evaluate financial metrics when studying reshoring but to also consider additional capabilities, for example quality, innovation and service (Miller and Roth, 1994; Sansone et al., 2020). While it is easy to say that 'money talks', there might be other prerequisites that are necessary, but not considered or not yet articulated. The unique case used here shows that there is reason to think that present manufacturing capabilities is one important prerequisite, but it might not be the only one. This research implies that there are antecedents to reshoring, which can lead to positive outcomes, which are not yet considered in research. It is, for example, commonly argued that companies reshore to be closer to the customers (Pearce, 2014, p. 34) or their headquarters (Bals et al., 2016p. 105), but the benefits of proximity might be offset by the current and planned manufacturing capabilities. While it has not been the main focus of this paper, the research was able to identify an important discussion about cost models at MainCo. The decision to include or exclude overhead costs needs to be better understood by researchers. It is possible that correct models about costs are not stale, but add costs to the product during a time period after its introduction. In relation, it is important to consider if there should be a direct link between how cost is calculated and how price is calculated.

The main implication for practitioners is perhaps not related to reshoring, but to offshoring. During offshoring, it is often argued that core activities should be kept in-house (Contractor et al., 2010). Companies that have kept control of these activities might also, unknowingly, prepared themselves for future reshoring. Companies that offshore with potential future reshoring in mind, might need to consider if the core activities are sufficient for future reshoring, or if some activities should be kept in-house, as to allow for easy retreat to domestic manufacturing. Perhaps this is also a political implication, where elected officials need to consider to what extent they encourage companies to keep some manufacturing in the company's home country. Managers that wish to strengthen their own plant, perhaps in competition with other plants in the same company, can improve their resource utilization and the performance of the plant by focusing on reshoring of the types of activities 
which have been outlined above. The research also highlights the importance of having appropriate cost models. Incorrect models can make reshoring efforts seem to have a negative economic impact (due to lower contribution margins), while actually increasing the profits of the manufacturing unit.

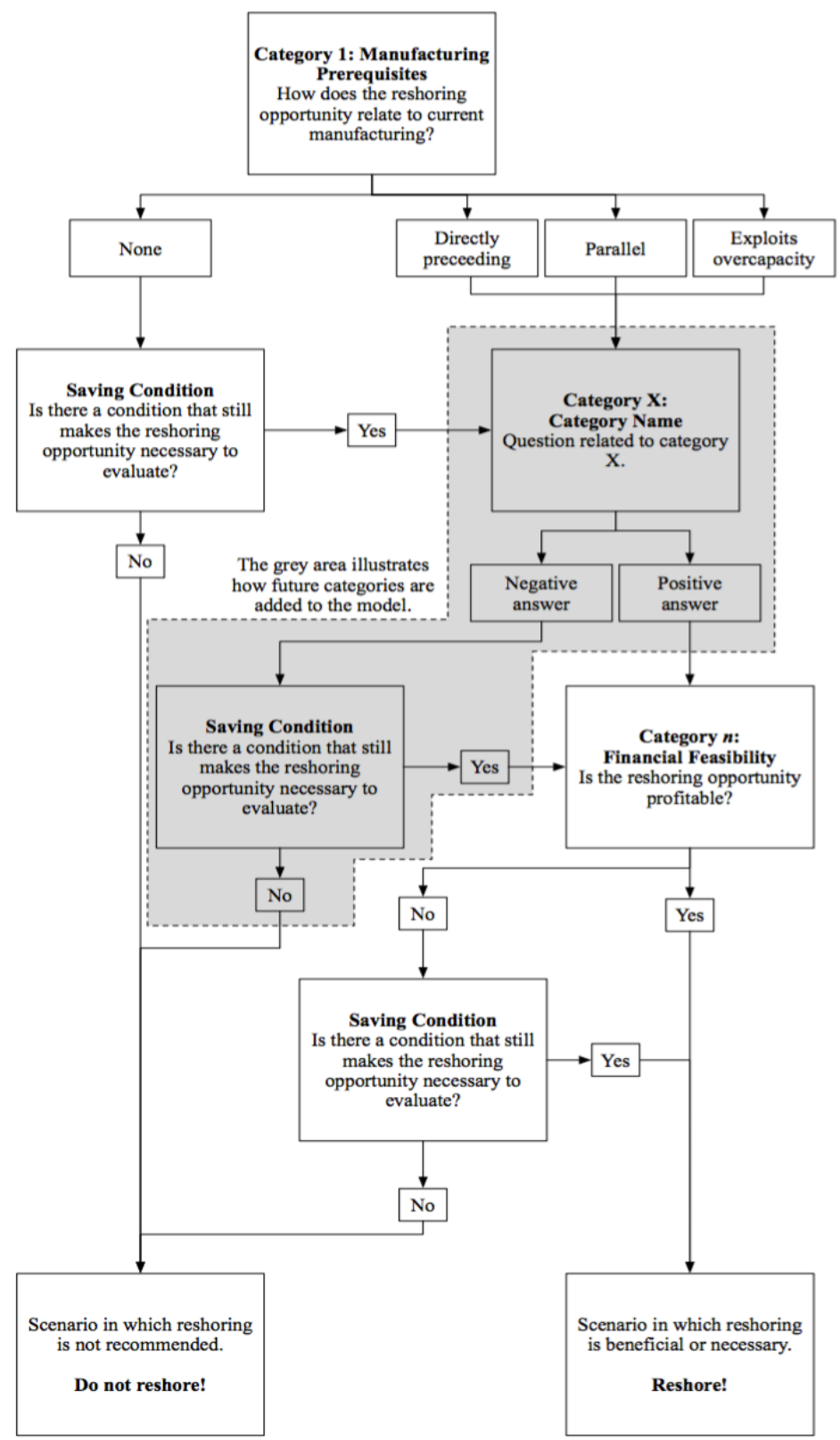

Figure 8 Proposed Model for Reshoring Decisions

\section{CONCLUSIONS AND FUTURE RESEARCH}

This paper set out to shed light on prerequisites for successful reshoring by looking specifically at manufacturing in high-cost locations. The focus is on the role of in-house manufacturing and how it is related to other manufacturing processes. This is distinct from earlier research, in which the focus has mainly been on financial metrics. Granted, such metrics are touched upon here, but have not been at the center of attention.

Current in-house manufacturing ensures that required skills and competencies are available. However, increasing production always puts the current capabilities to the test.
Currently, this is an area of research within reshoring that has not been gaining a lot of attention. This research identifies important scenarios that seem to be important to facilitate successful reshoring. The proposed scenarios are as follows: (1) Reshoring of directly preceding manufacturing steps

(2) Reshoring of parallel manufacturing steps

(3) Reshoring of steps that exploit overcapacity

All scenarios point to the importance of current manufacturing capabilities controlled by the company that is considering reshoring. While these findings are based on the empirical research from a small sample of companies, they have a high novelty value and expand on knowledge according to critical realism. The tentative conclusion is that it is of utmost importance to have manufacturing capabilities that either act as a seed to which reshored activities are 
added, or which are expanded into parallel lines. Already present manufacturing capabilities reduce the need for education of employees and investment in equipment. However, it also necessitates that there is some sort of consistency between products. In this case modularization was critical for smooth reshoring.

In future research, it is important to focus on the mediating role of existing manufacturing, for the success of reshoring initiatives. It is also important to develop our propositions into testable hypothesis, so that reshoring theory can be developed and improved.

\section{REFERENCES}

Aastrup, J. \& Halldórsson, Á. (2008). Epistemological role of case studies in logistics: A critical realist perspective. International Journal of Physical Distribution \& Logistics Management, 38(10), 746-763.

Ancarani, A., Di Mauro, C., \& Mascali, F. (2019). Backshoring strategy and the adoption of Industry 4.0: Evidence from Europe. Journal of World Business, 54(4), 360-371.

Arik, M. (2013). Framing the Offshoring and Re-shoring Debate: A Conceptual Framework. Journal of Global Business Management, 9(3), 73-83.

Arlbjørn, J.S. \& Mikkelsen, O.S. (2014). Backshoring manufacturing: Notes on an important but under-researched theme. Journal of Purchasing \& Supply Management, 20(1), 60-62.

Bailey, D. \& De Propris, L. (2014). Reshoring: opportunities and limits of manufacturing in the UK - the case of the auto sector. Revue D'Economie Industrielle, 145(1), 45-62.

Bals, L., Kirchoff, J.F. \& Foerstl, K. (2016). Exploring the reshoring and insourcing decision making process: toward an agenda for future research. Operations Management Research, 9(3), 102-116.

Barbieri, P., Ciabuschi, F., Fratocchi, L., \& Vignoli, M. (2018). What do we know about manufacturing reshoring? Journal of Global Operations and Strategic Sourcing, 11(1), 79-122.

Bhaskar, R., (1978). A realist theory of science Harvester Press: Hassocks, UK.

Canham, S. \& Hamilton, R.T. (2013). SME internationalisation: offshoring, 'backshoring', or staying at home in New Zealand. Strategic Outsourcing: An International Journal, 6(3), 277291.

Contractor, F.J., Kumar, V., Kundu, S.K. \& Pedersen, T. (2010). Reconceptualizing the Firm in a World of Outsourcing and Offshoring: The Organizational and Geographical Relocation of High-Value Company Functions. Journal of Management Studies, 47(8), 1417-1433.

Dachs, B., Kinkel, S., \& Jäger, A. (2019). Bringing it all back home? Backshoring of manufacturing activities and the adoption of Industry 4.0 technologies. Journal of World Business, 54(6), 1-15.

Danermark, B., Ekström, M., Jakobsen, L. \& Karlsson, J., (2003). Att förklara samhället Studentlitteratur: Lund, Sweden.

Dubois, A. \& Gadde, L.-E. (2002). Systematic Combining: An Abductive approach to Case Research. Journal of Business Research, 55(7), 553-560.

Dyer, W.G. \& Wilkins, A.L. (1991). Better stories, not better constructs, to generate better theory: a rejoinder to Eisenhardt. Academy of Management Review, 16(3), 613619.

Easton, G. (2010). Critical realism in case study research. Industrial Marketing Management, 39(1), 118-128.

Eisenhardt, K.M. (1989). Building Theories from Case Study Research. Academy of Management Review, 14(4), 532-550.

Ellram, L.M. (1996). The use of the case study method in logistics research. Journal of Business Logistics, 17(2), 93-138.
Ellram, L.M. (2013). Offshoring, reshoring and the manufacturing location decision. Journal of Supply Chain Management, 49(2), 3-5.

Ellram, L.M., Tate, W.L. \& Petersen, K.J. (2013). Offshoring and reshoring: an update on the manufacturing location decision. The Journal of Supply Chain Management, 49(3), 14-22.

Engström, G., Hilletofth, P., Eriksson, D., \& Sollander, K. (2018a). Drivers and barriers of reshoring in the Swedish manufacturing industry. World Review of Intermodal Transportation Research, 7(3), 195-220.

Engström, G., Sollander, K., Hilletofth, P., \& Eriksson, D. (2018b). Reshoring drivers and barriers in the Swedish

Eriksson, D. (2015). Lessons on Knowledge Creation in Supply Chain Management. European Business Review, 27(4), 346368.

Eriksson, D. \& Engström, A. (2020). Using critical realism and abduction to navigate theory and data in operations and supply chain management research. Supply Chain Management: An International Journal, xx(xx), xx-xx.

Fine, C. (2013). Intelli-sourcing to replace offshoring as supply chain transparency increases. Journal of Supply Chain Management, 49(2), 6-7.

Fraering, M. \& Prasad, S. (1999). International sourcing and logistics: an integrated model. Logistics Information Management, 12(6), 451-459.

Fratocchi, L., Di Mauro, C., Barbieri, P., Nassimbeni, G. \& Zanoni, A. (2014). When manufacturing moves back: Concepts and questions. Journal of Purchasing \& Supply Management, 20(1), 54-59.

Foerstl, K., Kirchoff, J. F., \& Bals, L. (2016). Reshoring and insourcing: drivers and future research directions. International Journal of Physical Distribution \& Logistics Management 46(5), 492-515.

Gray, J.V., Skowronski, K., Esenduran, G., \& Rungtusanatham, M. (2013). The reshoring phenomenon - what supply chain academics ought to know and should do. Journal of Supply Chain Management, 49(2), 27-33.

Gray, J. V., Esenduran, G., Rungtusanatham, M. J., \& Skowronski, K. (2017). Why in the world did they reshore? Examining small to medium-sized manufacturer decisions. Journal of Operations Management, 49, 37-51

Grossman, G.M. \& Rossi-Hansberg, E., (2006). Trading tasks: a simple theory of offshoring.

Gylling, M., Heikkilä, J., Jussila, K. \& Saarinen, M. (2015). Making decisions on offshore outsourcing and backshoring: A case study in the bicycle industry. International Journal of Production Economics, 162(92-100.

Hilletofth, P. (2008). Differentiated Supply Chain Strategy: Response to a Fragmentet and Complex Market, Lic Phil. Thesis, Chalmers University of Technology, Gothenburg, Sweden.

Hilletofth, P., Sequeira, M., and Adlemo, A. (2019), "Three novel fuzzy logic concepts applied to reshoring decision-making", Expert Systems with Applications, 126, 133-143

Kazmer, D.O. (2104). Manufacturing outsourcing, onshoring, and global equilibrium. Business Horizons, 57(4), 463-472.

Kinkel, S. (2014). Future and impact of backshoring-Some conclusions from 15 years of research on German practices. Journal of Purchasing \& Supply Management, 20(1), 63-65.

Kinkel, S. \& Maloca, S. (2009). Drivers and antecedents of manufacturing offshoring and backshoring - A German perspective. Journal of Purchasing \& Supply Management, 15(3), 154-165.

Kovács, G. \& Spens, K.M. (2005). Abductive Reasoning in Logistics Research. International Journal of Physical Distribution \& Logistics Management, 35(2), 132-144.

Lincoln, Y. \& Guba, E., (1985). Naturalistic inquiry Sage Publications: Beverly Hills, CA. 
Martínez-Mora, C. \& Merino, F. (2014). Offshoring in the Spanish footwear industry: A return journey? Journal of Purchasing \& Supply Management, 20(4), 225-237.

Mayring, P., (2010). Qualitative Inhaltsanalyse: Grundlagen und Techniken, 11th ed. Beltz Verlag: Weinheim, Germany.

Mcivor, R. (2013). Understanding the manufacturing location decision: the case for the transaction cost and capability perspectives. Journal of Supply Chain Management, 49(2), 23-26.

Miller, J.G. \& Roth, A.V. (1994). A taxonomy of manufacturing strategies. Management Science, 40(3), 285-304.

Ohno, T., (1988). Toyota Production System: Beyond Large-Scale Production Productivity Press: Portland, OR.

Pearce, J.A. (2014). Why domestic outsourcing is leading America's reemergence in global manufacturing. Business Horizons, 49(1), 27-36.

Sansone, C., Hilletofth, P., and Eriksson, D., (2020), "Critical operations capabilities for competitive manufacturing in a high-cost environment: a multiple case study", Operations and Supply Chain Management: An International Journal, 13(1), 96-109

Sayer, A., (1992). Method in Social Science - A Realist Approach, 2nd ed. Routledge: London, UK.

Taplin, I.M. (2006). Restructuring and Reconfiguration: The EU Textile and Clothing Industry Adapts to Change. European Business Review, 18(3), 172-186.

Tate, W.L., Ellram, L.M., Schoenherr, T. \& Petersen, K.J. (2014). Global competitive conditions driving the manufacturing location decision. Business Horizons, 57(3), 381-390.

Wiesmann, B., Snoei, J.R., Hilletofth, P. \& Eriksson, D. (2017). The reshoring conundrum: A literature on offshoring in reverse. 29(1), 15-42.

Wu, X. \& Zhang, F. (2014). Home or Overseas? An Analysis of Sourcing Strategies Under Competition. Management Science, 60(5), 1223-1240.

Yin, R.K., (2009). Case Study Research: Design and Methods Sage Publications: London, UK.

David Eriksson (PhD) is an associate professor at Jönköping University in Sweden. His research agenda consists of various research subjects including corporate social responsibility, methodology, new product development, supply chain management, sustainability, and waste management. He has editorial assignments with European Business Review, Industrial Management \& Data Systems, and World Review of Intermodal Transportation Research.

Per Hilletofth (PhD) is a Professor of Industrial Management at University of Gävle in Sweden. His research focuses on operations strategy, manufacturing location, supply chain design, new product development, and demand and supply integration. He has published articles in international journals including Supply Chain Management: An International Journal, Production Planning and Control, Expert Systems with Applications, Industrial Management and Data Systems, Journal of Business and Industrial Marketing, Innovation: Organization and Management, Journal of Manufacturing Technology Management, and European Business Review. He has editorial assignments in several international journals.

Wendy L. Tate (PhD) (Arizona State University 2006) is the William J. Taylor Professor of Business and the Cheryl Massingale Faculty Research Fellow in the Supply Chain Management Department at the University of Tennessee. She teaches at all levels including, undergraduate, masters and executive education Strategic Sourcing and Cost Management. She has an interest in the financial impacts of business decisions across the supply chain. Her research focuses on two primary business problems. The first is in the area of location decisions with regard to outsourcing and offshoring. The second is on sustainability initiatives and trying to understand how these can be diffused across a supply chain and a supply network.

Mikael Göthager (MSc) is a Management Consultant at CANEA Partner Group. He holds a MSc in Industrial Economics and Management. Beside his field of study, he has gained significant knowledge and practical experiences in Supply Chain Development from holding Strategic Development positions in Multinational corporations. He is specialized in the Lean and Six Sigma concepts, which outline the foundation of his Supply Chain Development perspective and methodology. As a Management Consultant, he teaches the Operational Improvement concepts in both theory and practice, along with driving strategic development projects within Supply Chain Operations. 